\title{
Assessment of Climate Variability in Kisii Kenya and Its Implications on Food Security
}

\author{
Moranga Patrice Samwel, Romulus Abila* ${ }^{\mathbb{C},}$, Samson Mabwoga \\ Department of Environment Studies, Geography and Agriculture Maasai Mara University, Narok, Kenya \\ Email: ^abila@mmarau.ac.ke
}

How to cite this paper: Samwel, M. P., Abila, R., \& Mabwoga, S. (2021). Assessment of Climate Variability in Kisii Kenya and Its Implications on Food Security. American Journal of Climate Change, 10, 386-395. https://doi.org/10.4236/ajcc.2021.104019

Received: June 22, 2021

Accepted: November 16, 2021

Published: November 19, 2021

Copyright $\odot 2021$ by author(s) and Scientific Research Publishing Inc. This work is licensed under the Creative Commons Attribution International License (CC BY 4.0).

http://creativecommons.org/licenses/by/4.0/

(c) (i) Open Access

\begin{abstract}
Climate change and variability have been singled out as one of the modern challenges that affect economies of several countries leading to food scarcity and food insecurity in various parts of the world and represent a fundamental contemporary environmental shock. Kenya is no exception. This research was conducted in Kisii County, a perceived Kenyan national bread basket and investigated the trend in climate variability between the years 1983-2013. The objective of the study was to examine the precipitation and temperature trend in Kisii County. The research question was to find out whether there was any significant trend and pattern of rainfall and temperature as indicators of climate variability. The study examined climate variability for thirty one years (1983 to 2013). Data was obtained from Kenya Meteorological Department and their annual means were computed. Mann Kendall statistic test was applied to establish whether the observed trend of precipitation and temperature was significant. From the analysis, rainfall did not show any significant trend in Kisii County whilst temperature revealed a significantly upward trend over the years, at $95 \%$ confidence level. The study recommends a need to incorporate weather prediction and early warning systems by the Ministry of Agriculture in Kisii County and also promote afforestation programmes to protect water catchments. To build resilient systems to climate shocks, introduction of high temperature tolerant food crops as well as adoption of climate smart agriculture (CSA) should also be explored.
\end{abstract}

\section{Keywords}

Climate Shocks, Climate Smart Agriculture, Mann Kendall Statistics, Rainfall, SDG 1, SDG 2, Temperature

\section{Introduction}

Climate change and variability may be caused by natural processes or by human 
influences. The natural processes include volcanoes, internal variability in climatic factors or sun's radiation. Human activities that influence climatic change alongside land use changes include, release of greenhouse gases and changing concentration of suspended particulate matter in the atmosphere (Rosso, 2018). Climate alteration affects directly food systems and food accessibility globally (Ray et al., 2019) and may perhaps be the single most important factor affecting realization of UN Sustainable Development Goals 1 and 2. Since climate change happens slowly and gradually, it is hard to be perceived in the absence of scientific data. Scientists detect climate change by examining average trends of climatic elements occurring in a span of time. Changes happening in the earth's environment, may originate from the revolution of the earth around the sun or they may be caused by human modification of the environment, hence leading to climate change (Tranter, 2017; Ebele \& Emondi, 2016). The rate at which climate change is taking place in modern times is quite high, compared to what has been witnessed before the pre industrial period. Temperatures are on upward trend globally with strong evidence linking human related activities on the surface of the earth (Rosso, 2018).

In the horn of Africa, Ghebrezgabher et al. (2016) investigated long term trends of climate change and droughts. The study collected information from 46 weather stations located within and outside the region. Their result showed that, rainfall and temperature oscillated up and down at a rate of -0.3913 and 0.0084 per year. The trend for rainfall was not significant at $95 \%$ confidence interval while the trend for temperature was significant at $99 \%$ confidence level. The peak amount of rainfall was captured in 1961, 1967 and 1997 while the lowest was recorded in 1943,1984 , and 2009 . The warmest year was in 2009 by $1.004^{\circ} \mathrm{C}$. In Southern Africa Development Community (SADC) region, rainfall trend from 1960 to 1996 was analyzed by Mpadeli et al. (2018) who showed that precipitation was extremely variable between 1960-1961 and 1988-1989. However, from 1989-1990 onward, the rainfall variability was dominated by a decline in rainfall amounts mainly in summer. This reduction in rainfall impacted negatively in food production hence exacerbating SADC vulnerability to hunger. The study further revealed that, during 2015/2016 El Niño Southern Oscillation (ENSO), the induced drought was estimated to have affected over 40 million people who became food insecure, by not only causing 643,000 livestock deaths but also caused a short fall of 5.1 million tons in maize production.

In another study in South Africa by van Wilgen et al. (2016) investigating temperature and rainfall trends, data was computed for 80 years. The findings from the research indicated that, there was a vital yearly increase in one of the temperature variables in nine out of 13 weather stations. Weather stations located in north western parks such as Kalahari, Gemshock, Richtersveld and Aurabiesfall, revealed greatest increase in temperature trend. In those other ones located in the parks and had data for 50 years, they showed that, maximum temperature had risen by $1.95^{\circ} \mathrm{C}$ since 1960 . On precipitation patterns, 
the study indicated that no significant trend was detected across the study area.

Climate change is clearly manifesting itself in Eastern Africa and is increasing at a frightening pace, informed by the rising temperature and rainfall unpredictability whereby, some parts of Kenya, Ethiopia and Tanzania experience rainfall that has no significant trend (Gebrechorkos et al., 2019). This has made Kenya to be vulnerable to the impacts of climate change. In a research done by Marigi (2017) in the southern Kenya, data was collected from five weather stations namely; Makindu, Katumani, Mutomo, Kitui and Mwingi. Mann Kendall's Tau test was used to compute the trends. The findings were that, the trend for heavy rainfall days were decreasing while the frequency of the number of warm days had increased in the area. For instance at Katumani and Makindu weather stations, there was an increase in the number of warmer days that were over $25^{\circ} \mathrm{C}$ at $5 \%$ significance level. In addition, the frequency of cold nights was also on the increase. Minimum temperature of less than $10^{\text {th }}$ percentile was on upward trend in Katumani and Kitui stations at 5\% significance level. On days with maximum temperature of less than $10^{\text {th }}$ percentile of maximum temperatures, cold day time was on a decreasing trend as the frequency of warmer nights increased.

Effects of climate change in Kenya mainly depend on the region's exposure, sensitivity and its adaptation. For instance droughts and floods have accounted for the highest impacts that have caused colossal economic losses in terms of destroyed property and loss of livelihood such as staple crops like maize and cash crops like tea Marigi et al. (2016).

Temperature and precipitation changes are two climatic elements which are of great concern to agricultural productivity in Kenya. For instance both minimum and maximum temperatures on the normal average seasons of December to February, March to May and September to November, exhibit a rise in temperature across the northern parts of Kenya while some parts have no well defined patterns of precipitation trend due to their high spatial variability (Indeje et al., 2000). The climate change that is being felt in Kenya is happening at an alarming rate hence endangering natural resources. Climate change which is enhanced by unsustainable land use activities is accelerating expansion of the ASAL regions in Kenya (Narok County Government, 2018). In addition, the increasing trend in temperature and much longer periods of drought may not only lead to more frequent and intense forest fires but also may expand the ecosystem range of pests and other pathogens which adversely food production (Madegwa et al., 2016). The frequency and intensity of climate change events, such as drought and floods have also taken toll of productive assets, personal property and even life in some parts of Kenya. Famine cycles have been worsening from 20 years in 1964-1984 to 12, and in 1984-96 to 2 years, 2004-2006 onwards to date, almost yearly (GOK, 2010). This has made the government of Kenya spend huge sums of money estimated to be 20 billion between 2005-2009 in providing food to feed a population of about 3.5 - 4.5 million people every year (GOK, 2010). Food shortages may continue in Kenya since large areas in Kenya have witnessed 
more than $100 \mathrm{~mm}$ drop in rainfall during the long rains season by 2010 (FEWS, 2010). This decline has made the acreage of the area under crop production to also decrease making the agricultural production in Kenya to be on a downward trend (Patel et al., 2012; AFIDEP, 2012). Comparatively before 1970, agricultural production rate in Kenya was 4.8\% p.a., but between 1980-1990 the production rate declined to $3.3 \%$ and then worsened to $1.7 \%$ between 1990-2000 (Patel et al., 2012). Such a decline further worsens the fact that about $75 \%$ of the populace in Kenya earn their livelihood or partly depend on farming and agricultural related activities for their survival. Worse still, the ongoing subdivision of the arable land per capita, is now about 0.96 ha in high population density areas (Muyanga \& Jayne, 2014). Yields from small plots are exacerbated by frequent droughts and floods (Patel et al., 2012) that lead to perpetual food insecurity that is experienced in the country, which may lead to malnutrition. In central Kenya, the biggest challenge facing farmers in market gardening is unpredictable rains and lack irrigation tools (Ndukhu et al., 2016). Changes in climatic variables such as rainfall and temperature affect crop productivity in situations where rainfall delays in its commencement, or is accompanied with occasional erratic floods that cause damage to crops.

The Kisii agro-ecological region is considered one of Kenya's breadbaskets where cash and food crops such as maize, beans and bananas are grown. Sustaining the region's agricultural production is vital if Kisii County is to sustain and make gains on poverty eradication, end hunger, achieve food security and improved nutrition and promote sustainable agriculture thus contributing to achievement of Sustainable Development Goals (SDGs) 1 and 2. The objective of this study was to determine temperature and rainfall trends in Kisii over a 31 year period as a first step towards providing evidence that can inform new agricultural practices and policies aimed at mitigating adverse affects of climate variability.

\section{Methodology}

\subsection{Study Area}

Kisii County is made up of Marani, Kisii South, Gucha South, Bomachoge Borabu, Bomachoge Chache, Nyamache, Kisii central, Sameta, and Masaba South. The study was carried out in Marani and Bomachoge Chache sub counties. Marani and Bomachoge Chache were purposively targeted because they had the largest number of food security programmes (Kisii County Governmnet, 2013). Kisii County borders Narok to the south, Nyamira County to the East, Homabay County to the North and Migori County to the West. The altitude of the County ranges between $1500 \mathrm{~m}-1800 \mathrm{~m}$ above sea level. It experiences double maxima rainfall during March, April, and May and also in October, November and December. It has an average annual rainfall of about $1500 \mathrm{~mm}$ per year. The County is located along latitude $0^{\circ} 41^{\prime} \mathrm{S}$ and Longitude $34^{\circ} 36^{\prime} \mathrm{E}$ (Figure 1 ).

Kisii County has a population of 1,266,860 and 304,054 households (Kenya 


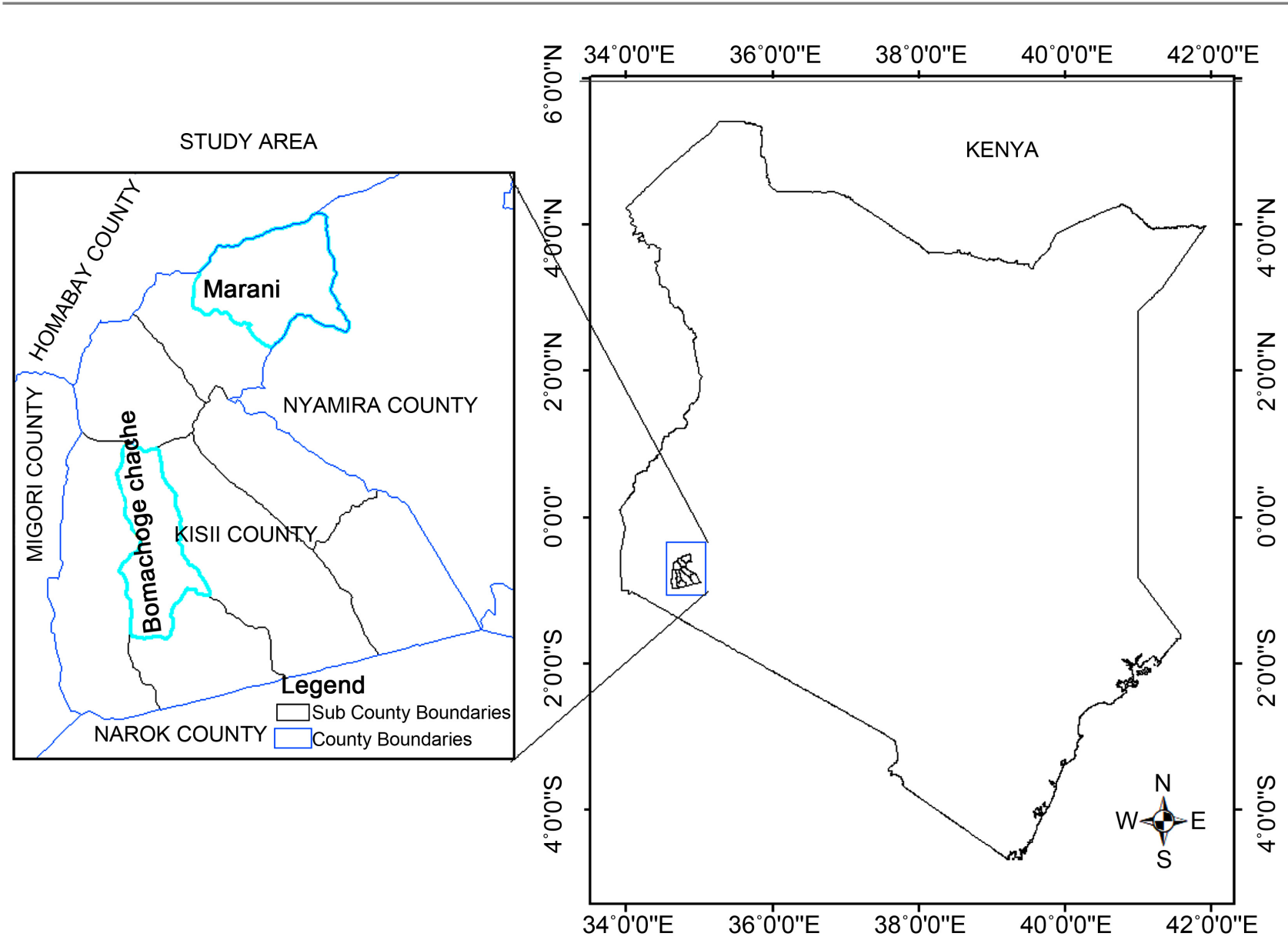

Figure 1. Map showing Kisii county constituencies (source: Kisii County Government, 2018).

National Bureau of Statistics, 2019) whereby 605,784 were males, 661,038 females and 38 intersex. The County total area is $2542 \mathrm{~km}^{2}$ and it has a population density of 958 inhabitants per $\mathrm{km}^{2}$ (Kenya National Bureau of Statistics, 2019) making it one of the most highly densely populated counties in Kenya. It has a high agricultural potential area and its economic activities include subsistence farming, dairy farming, small scale tea and coffee farming. In 2012, the county received both long and short rains which were above long term mean leading to flooding that destroyed the production of beans. It has food poverty percentage of $60 \%$ and it is majorly affected by droughts and floods (Kisii County Government, 2013). Even though Kisii County has a high economic potential, about $44.5 \%$ of its population live below poverty line (Kisii County Government, 2018).

\subsection{Sampling Technique}

Purposive sampling technique was applied to identify Kenya Meteorological officers at National and county level. This technique permits a researcher to make use of cases possessing the required information (Tongco, 2006; Mugenda, 2008).

\subsection{Data Collection}

In this research work, secondary statistics were accessed at the Kenya Agricul- 
tural and Livestock Research Organization (KALRO) offices and Coffee substation weather stations in Kisii County. Rainfall and temperature trends for the last 31 years were analyzed.

\subsection{Data Analysis}

The duration of 31 years was taken because it is above the minimum threshold that is required for the observation of average weather conditions of a place in order to determine its climate (WMO, 2017). Rainfall and temperature data (only available up to 2013) was analyzed from two weather stations in Kisii County. The measurable variables were, rainfall totals, minimum temperature and maximum temperatures. The annual average readings were computed and then subjected to Mann Kendall test analysis.

The Mann Kendall test was used to calculate statistic value (S) and the probability value $Z$. A positive value $S$ indicates an increasing trend, a negative $S$ value shows a decreasing trend, while a zero value denotes no trend (Ahmad et al,, 2015). In addition, the probability value associated with value $S$ and the sample size value was computed in order to quantify the significance of the trend observed.

\section{Results}

\subsection{Changes in Precipitation in Kisii County between 1983 and 2013}

Figure 2 shows the average precipitation of Kenya Agriculture and Livestock

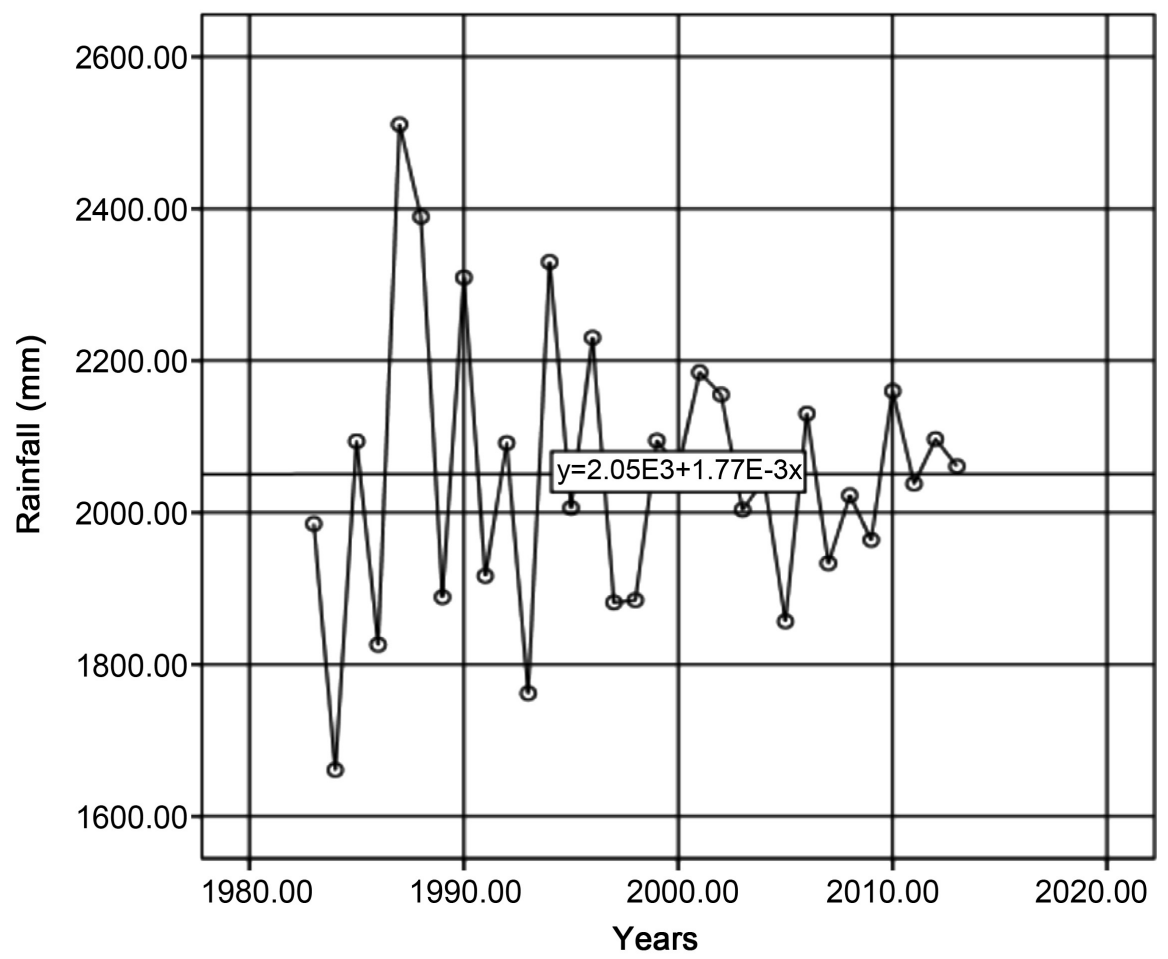

Figure 2. Average precipitation between 1983-2013 in two weather station in Kisii. 
Max. and Min. Temperature Trends

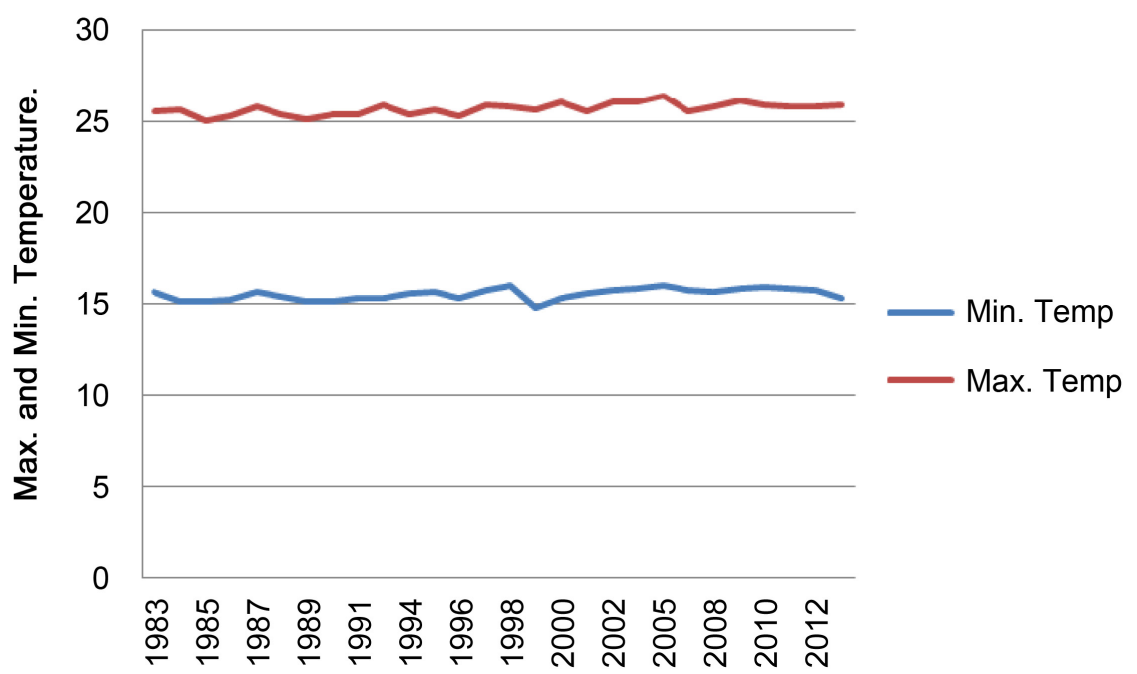

Figure 3. Average temperature variation in Kisii between 1983-2013.

Research Organization (KALRO) weather station and Kisii coffee substation from 1983 to 2013. The $\mathrm{p}$ value computed using Mann Kendall test was 0.590 ( $\mathrm{p}>$ 0.05). There was no trend in average precipitation in the two weather stations. This corroborate the findings of Gebrechorkos, 2019; Indeje et al., 2000 that some regions in Kenya, Ethiopia and Tanzania do not have clear patterns of precipitation indices as result of rainfall variability largely brought about by local factors and not by large scale factors.

\subsection{Kisii Average Minimum and Maximum Temperature Trend Time Series}

Figure 3 shows Kisii average minimum and maximum temperature trend series. From the figure, the mean temperatures have been rising in KALRO weather station. The computed Mann Kendall $p$ value of $0.001(p<0.05)$ reveals that temperatures are rising over Kisii at a significant pace, since the $p$ value is not greater than alpha level of 0.05 .

\section{Discussion}

In Africa, most countries heavily depend on rain fed agriculture hence they have fragile economies leading to food shortages as result of climatic stresses that include droughts and floods. Food shortages in most of these countries require the intervention of colossal sums of money to reduce the impact of famine. There is therefore need for studies to provide data on climatic factors that may affect food production. The specific objective of this study was to examine temperature and rainfall trends in Kisii County for a period of 31 years and what implications these may have on food production hence food security as Kisii County is considered one of Kenya's food baskets. From the outcome of the research, rainfall in both weather stations has been falling but Mann Kendall test did not reveal 
any significant trend. Conversely on the minimum and maximum temperature, the Mann Kendall test showed a rising trend which was significant. This means that, the increased temperature correspondingly increases the water holding capacity of the atmosphere. The increased atmospheric water holding capacity promotes evapo-transpiration from the surface hence reducing moisture in the soil. Deficiency of moisture in the soil may lower agricultural production in Kisii County. Elevated temperatures are often associated with increased incidences of crop pests and diseases which affect food production and will most likely affect food production in Kisii. Higher temperatures may also affect underground water resources such as springs and wetlands through increased rates of evaporation thereby reducing availability of water for irrigation agriculture (IPCC, 2014). Elsewhere similar observations were revealed by Muhati et al. (2018) that temperature around sub humid Montane forest in Northern Kenya realized a significant increase in annual temperature between 1974 and 2011.

Kenya's population is currently estimated at nearly 54 million (Worldometers.info, 2021) and nearly $80 \%$ of the population live within the historically recognized high agricultural potential areas. Climate change and land use changes have been recognized as major factors that may lead to erosion of gains made towards securing food security in developing countries (UNFCC, 2020). This study suggests that, there have been significant changes in temperature in Kisii between 1983 and 2013. To safeguard agricultural production in the Kisii agroecological zones and similar regions in Kenya under changing climatic conditions, research should be undertaken, aimed at incorporating weather prediction and early warning systems in agricultural practices, promoting afforestation to protect water catchments, and building resilient systems to climate shock for example by introducing high temperature tolerant crops including genetically modified strains of currently grown crops. These approaches have largely been instituted in Kenya's Arid and Semi Arid Lands (ASAL). Secondly, education and awareness creation need to be undertaken to sensitize farmers on climate change and its effects and farmers are trained on adoption of climate smart agricultural practices.

\section{Acknowledgements}

This work was supported by Maasai Mara University as part of MA (Geography) Master thesis research. We thank all respondents who took their time to answer the questionnaires as well as the anonymous manuscript reviewers. We also thank Kenya Meteorological Department for freely availing climate data.

\section{Conflicts of Interest}

The authors declare no conflicts of interest regarding the publication of this paper.

\section{References}

African Institute for Development Policy (AFIDEP) (2012). Population Climate Change, 
and Sustainable Development in Kenya. Bridging, Development Research Policy and Practice (1-4). African Institute for Development Policy.

https://www.afidep.org/publication/population-dynamics-climate-change-and-sustaina ble-development-in-kenya/

Ahmad, I., Tang, D., Fang, T. W., Wang, M., \& Wegan, B. (2015). Precipitation Trends over Time Using Mann Kendall and Spearman Rho Test in Swat River Basin, Pakistan. Advances in Meteorology, 2015, Article ID: 431860. https://doi.org/10.1155/2015/431860

Ebele N, E., \& Emondi, N. V. (2016). Climate Change and Its Impacts on Nigerian Economy. Journal of Scientific Research and Reports, 10, Article No. JSRR.22162. https://doi.org/10.9734/JSRR/2016/25162

Famine Early Warning System (FEWS) (2010). A Climate Trend Analysis of Kenya-August 2010.USGS Science for Changing World. Rolla Denvar Publishing Service Centres.

Gebrechorkos, S. H., Hülsmann, S., \& Bernhofer, C. (2019). Long-Term Trends in Rainfall and Temperature Using High-Resolution Climate Datasets in East Africa. Scientific Reports, Article No. 11376. https://doi.org/10.1038/s41598-019-47933-8

Ghebrezgabher, M., Yang, T., \& Yang, X. (2016). Long Term Trend of Climate Change and Drought Assessment in the Horn of Africa. Advances in Meteorology, 2016, Article ID: 8057641. https://doi.org/10.1155/2016/8057641

Government of Kenya (GOK) (2010). Short Rains Assessment Report (pp. 1-42). Kenya Food Security Steering Group.

Indeje, M., Semazzi, F. H. M., \& Ogallo, L. J. (2000). ENSO Signals in E. African Rainfall seasons. International Journal of Climatology, 20, 19-46. https://doi.org/10.1002/(SICI)1097-0088(200001)20:1\%3C19::AID-JOC449\%3E3.0.CO; $\underline{2-0}$

IPCC (Intergovernmental Panel on Climate Change) (2014). Summary for Policymakers. In O. Edenhofer, R. Pichs-Madruga, Y. Sokona, E. Farahani, S. Kadner, K. Seyboth et al. (Eds.), Climate Change 2014: Mitigation of Climate Change. Contribution of Working Group III to the Fifth Assessment Report of the Intergovernmental Panel on Climate Change (pp. 1-32). Cambridge University Press.

Kenya National Bureau of Statistics (2019). 2019 Kenya Population and Housing Census Vol. IV: Distribution of Population by Socio-Economic Characteristics. Kenya National Bureau of Statistics.

Kisii County Government (2013). The First County Integrated Development Plan 2013-2017 (14-126). Kisii County Government.

Kisii County Government (2018). County Integrated Development Plan 2018-2022. Kisii County Government.

Madegwa, Y., Richard, O., Solomon, S. S., \& George, K. (2016). Farmers Perception and Adaptation strategies in Climate Change in Lower Eastern Kenya. A Case of Finger Millet (Ebusine coracana (L)) Gaertn Production. Journal of Agricultural Science, 8, 33-40. https://doi.org/10.5539/jas.v8n12p33

Marigi, S. N, Njogu, A. K., \& Githunguro, W. (2016). Trends of Extreme Temperature and Rainfall Indicaters for Arid and Semi Arid Lands of South Eastern Kenya. Journal of Geoscience and Environment Protection, 4, 158-171. https://doi.org/10.4236/gep.2016.412012

Marigi, S. N. (2017). Climate Change Vulnerability and Impacts Analysis in Kenya. American Journal of Climate Change, 6, 52-74. https://doi.org/10.4236/ajcc.2017.61004

Mpadeli, S., Dhesigen, N., Tafadwanashe, M., Charles, N., Nhamo, L., Stanley Liphadzi, M., Hlahla, S., \& Modi, A. T. (2018). Climate Change Adaptation through the Water 
Energy Food Nexus in Southern Africa. Journal of Environmental Research and Public Health, 15, Article No. 2306. https://doi.org/10.3390/ijerph15102306

Mugenda, A. G. (2008). Social Sciences Research. Applied Research and Training Services: Kenya (pp. 193-196). ACTS, Nairobi.

Muhati, G. L., Daniel, O., \& Lydia, O. (2018). Past and Projected Rainfall and Temperature Trends in a Sub-Humid Montane Forest in Northern Kenya Based on the CMIP5 Model Ensemble. Global Ecology and Conservation, 16, Article ID: e00469. https://doi.org/10.1016/j.gecco.2018.e00469

Muyanga, M., \& Jayne, T. S. (2014). Effects of Rising Rural Population Density on Smallholder Agriculture in Kenya. Food Policy, 48, 98-113. https://doi.org/10.1016/j.foodpol.2014.03.001

Narok County Government (2018) Narok County Integrated Development Plan, 2018-2022. http://repository.kippra.or.ke/bitstream/handle/123456789/970/Narok\%20County\%20I ntegrated\%20Development\%20plan\%202018-2022.pdf? sequence $=1$ \&isAllowed $=y$

Ndukhu, O. N., Onwonga, W. G., Kironchi, R. G., \& Henning, J. H. (2016). Assessment of Organic Farming Knowledge and Adaptation Strategies to Climate Change and Variability in Central Kenya. British Journal of Applied Science \& Technology, 17, 1-22. https://doi.org/10.9734/BJAST/2016/16270

Patel, P. N., Mbagaya, G. M., \& Imo, B. E. (2012). Impact of Climate Change on Food and Nutrition Security in Kenya. International Journal of current research, 4, 242-248. https://www.journalcra.com/sites/default/files/issue-pdf/1573.pdf

Ray, D. K, West, P. C., Clark, M., Gerber, J. S., Prishchepov, A. V., \& Chatterjee S (2019). Climate Change Has Likely Affected Global Food Production. PLoS ONE, 14, Article ID: e0217148. https://doi.org/10.1371/journal.pone.0217148

Rosso, M. G. (2018). Climate Change and Individual. American Journal of Comparative Law, 66, 345-378. https://doi.org/10.1093/ajcl/avy018

Tongco, M. (2006). Purposive Sampling as a Tool for Informant Selection. Ethnobotany Research and Applications, 5, 147-158. https://doi.org/10.17348/era.5.0.147-158

Tranter, B. (2017). It is Only Natural: Conservatives and Climate Change in Australia. Environmental Sociology, 3, 274-285. https://doi.org/10.1080/23251042.2017.1310966

United Nations Framework Convention on Climate Change (UNFCC) (2020). Climate Change Is an Increasing Threat to Africa.

https://unfccc.int/news/climate-change-is-an-increasing-threat-to-africa

van Wilgen, N. J., Goodall, V., Holness, S., Chown, S. L., \& McGeoch, M. A. (2016). Rising Temperature and Changing Rainfall Patterns in S. Africans National Parks. International Journal of Climatology, 36, 706-721. https://doi.org/10.1002/joc.4377

World Meteorological Organization (WMO) (2017). Guidelines on the Calculation of Climate Normals (WMO No. 1203). World Meteorological Organization.

Worldometers.info (2021). World Population by Countries-Kenya. https://www.worldometers.info/world-population/kenya-population/ 